\title{
Sustainability of an Urban Teacher Education Program
}

\author{
Laura Atkinson ${ }^{1}$, Sarup R. Mathur ${ }^{1} \&$ Stanley H. Zucker ${ }^{1}$ \\ ${ }^{1}$ Mary Lou Fulton Teachers College, Arizona State University, Tempe, USA \\ Correspondence: Sarup R. Mathur, Mary Lou Fulton Teachers College, Arizona State University, Tempe, USA. \\ Tel: 1-480-965-6893. E-mail: sarup.mathur@asu.edu
}

Received: October 11, 2019

Accepted: November 23, 2019

Online Published: December 14, 2019

doi:10.20849/jed.v3i3.680

URL: https://doi.org/10.20849/jed.v3i3.680

\begin{abstract}
Most of the teacher preparation programs in the United States adhere to a traditional curriculum that includes courses in foundations, liberal arts, methods, and student teaching. Too often these programs fail to provide opportunities for culturally responsive teaching where teacher candidates are encouraged to explore the role of culture in developing identity, providing space for learning, and building communities. A one-year Urban Teacher Education Program (UTEP) was created that focused on preparing teachers to work with disadvantaged, underprivileged, and marginalized children in urban schools. Teacher candidates received spaces to question their own thinking and reflect about issues related to (1) identity, (2) culture, (3) learning, and (4) assessment during this program. Four years after program completion, five participants from UTEP were selected for this study. The study used a mixed method approach to measure maintenance in transformation in their thinking. The results showed sustainability of the impact of the program four years later.
\end{abstract}

Keywords: sustainability, urban teacher education, identity, inclusive education, reflection

\section{Introduction}

\subsection{Introduction of the Problem}

Educators need to continuously refine their practices to meet the needs of diverse learners in urban schools. Urban students bring to schools their unique cultural strengths and learning experiences that must be incorporated in the curriculum, instruction, and school routines. Kozleski, Gonzalez, Atkinson, Lacy, \& Mruczek, (2013) reported that most of the teaching force, including special educators, identifies as $83 \%$ White $7.2 \%$ Hispanic, 6.9\% Black, 1.6\% Asian, and 0.8\% American Indian/Alaska Native (Aud et al., 2011). In contrast, the student population is shifting rapidly and, in some states most students identify as Hispanic, Black, Asian, and American Indian/Alaska Native (Kozleski et al. 2013). The teaching force is not keeping up with the student population that is becoming increasingly diverse. Thus, many teachers who work in urban schools may not have the knowledge, skills, and dispositions to design and deliver culturally responsive curriculum and pedagogies. Ukpokodu (2012) suggests that, as a result, teachers are likely to lower their expectations for their students, which in turn influences student outcomes, by becoming self-fulfilling prophecies. The teaching force needs to be able to address cultural histories and experiences within the core curriculum in schools. Research indicates that non-Black teachers have lower expectations of Black students and are less likely to believe that they will complete four-year College (Gerhenson, Holt, \& Papageorge, 2015). Many educators view Asian Americans as "whiz kids' or the "model minority" going to ivy schools, and fail to recognize challenges, and barriers experienced by numerous subgroups of Asian American students (Blackburn, 2019). Providing teachers with opportunities to challenge unconscious bias that they bring to their teaching helps them reconsider what constitutes equity in practice (Kozleski et al. 2013).

\subsection{Importance of the Problem}

A criticism leveled at current teacher preparation programs is that they often prepare their graduates to reproduce the dominant culture, practices, and knowledge (Kozleski \& Waitoller, 2010). By focusing on technical, performance skills rather than activating framing lens for examining and improving practice and relationships in the classroom, some programs produce teachers who may be poorly equipped to examine the ways in which they use a dominant cultural lens to perpetuate structural and practice inequities found in classrooms (Kozleski et al. 2013). In contrast, the UTEP was designed to help its graduates become aware of and critically examine ways in which the dominant culture, practices and knowledge impact the classroom, and to explore ways of making the 
classroom more inclusive to all cultures on an ongoing basis.

\subsection{Contextual Information About UTEP and Relevant Scholarship}

The work of Singer, Catapano, and Huisman (2010) remind us that we need to advocate for redesigning teacher preparation programs to provide experiences for preservice teachers that depict the realities of urban schools for them to truly understand the culture and the community in which they will be working in. It is crucial for teacher preparation programs to address the "demographic denial" (Gutierrez et al., p. 340), where teachers believe that all students have come from the same background and culture. Instead of denying their diverse needs, they need to align curriculum and instruction to support the needs of urban learners. This work needs to be embedded in the content knowledge and pedagogical practices that teachers develop in their practice as special and general educators. Without making these ideas explicit in teacher education curriculum, teachers will lack the cultural and intercultural frames and practices that will connect to new generations of students in American public schools. To address this issue, the UTEP curriculum was shaped by the belief that the teacher residents should learn to critically consider their own thinking and reflect on their beliefs about working with children from diverse urban settings.

UTEP was patterned after teaching hospitals, where medical students refine their skills in "real life" situations in a structured learning environment by participating in a comprehensive residency under the close supervision of highly qualified and experienced mentors (Goodlad, 1990). Similar to a residency in the field of medicine, UTEP placed teacher residents in "real" classrooms for a substantial amount of time, more than 800 hours, and provided them access to highly qualified mentors. The mentor teachers in UTEP were carefully selected by the school administrators and met the school districts criterion for a master teacher. The overall learning environment in the UTEP was called a Professional Learning School (PLS) (Kozleski \& Waitoller, 2010). The PLS component in UTEP was conceptualized by combining elements of a professional development school (PDS) and a professional learning community (PLC). By adopting the features of PDS, which concentrated on the school district and university partnership; implementing staff development to bridge theory and practice; and using the component of a PLC that shared the vision of change and continual improvement (Hoffman, Dahlman, \& Zierdt, 2009), the UTEP PLS was formed. The PLS was designed to foster collaboration amongst all parties involved to reach a common goal, that is, ways to improve student outcomes.

The program consisted of four semesters spanning a year (summer, fall, spring, summer). It was designed to improve classroom practices and student outcomes by focusing on four themes: identity, culture, learning, and assessment from a cultural psychology lens (see Kozleski \& Waitoller, 2010 and Waitoller, \& Kozleski, 2013 for a full program description). The program provided opportunities for teacher residents to be immersed in an urban school setting while thinking critically about issues surrounding these four themes. The goal was to encourage the teacher residents to critically reflect on their own thinking in regards to creating learning spaces for students with diverse backgrounds, skills, interests, and abilities (Kozleski \& Waitoller, 2010). The critical reflection component was aligned with the work of Howard (2003) who proposed that critical reflection was an attempt "to look at reflection within moral, political, and ethical contexts of teaching" (p. 197). Every semester, teacher residents were required to take a seminar course that promoted teacher inquiry. The authors refer to teacher inquiry as defined by Dana and Yendol-Silva (2003) that states "Teacher inquiry as a systematic, intentional study of one's own professional practice" (p. 5). Teacher residents examined their own practices and interrogated their own beliefs and assumptions about working with students in urban settings. When the UTEP teacher residents engaged in teacher inquiry during their seminar courses, they took charge of constructing their own knowledge and read pieces from current literature, openly discussed the readings, and engaged in critical reflection and enhanced their understanding about the issues they encapsulated.

Students were selected to participate in the program because they perceived that their respective initial teacher preparation programs did not prepare them to work in urban schools. The program immersed students-labeled by the program as teacher residents - in the teaching profession by engaging them in an urban school and having them work closely with their assigned mentor teacher. In UTEP, urban schools were defined as those schools that were situated in (a) compactly populated, diverse, primarily minority-majority neighborhoods; (b) communities with limited access to financial resources, jobs, health care, transportation, physical safety and modernized facilities; and (c) familial cultures within communities that were historically marginalized by the dominant cultures within the United States (Anyon, 1997; Buendia, 2010; Kozleski \& Smith, 2009).

These urban schools exposed teacher residents to a diverse set of cultural and socioeconomic settings. In these diverse settings, teacher residents worked closely with their clinical teachers to reflect on their role in creating inclusive and participatory classrooms. They brought back the elements of inclusive education and explained 
how they were reflected in this program. The teacher residents co-taught with their clinical teacher during their first semester. This collaborative experience allowed the two teachers to work as a team and support the learning of all students in their classroom. The teachers had planning time and were able to reflect on their collaborative efforts. The teachers in UTEP were provided with prompts that they had to address on a weekly basis in their practicum course. This exercise encouraged the teacher residents to consider ways of including their students' culture into everyday educational practice including the curriculum. Site coordinators and site professors provided feedback to teacher residents when they taught or co-taught lessons and provided continuous mentoring and coaching to them. Teacher residents developed a portfolio that showed their reflective learning about the four themes as they moved through the program.

\subsection{Rationale for the Present Study and Research Question}

The Kozleski et al. (2013) study examined how tensions emerged in teacher preparation when theory intersected with realities of daily life in schools and politics restricted the opportunities for inclusive education. Three themes emerged as teacher residents negotiated their understanding of and commitment for inclusive education: (a) critical reflection as an emergent practice, (b) teacher learning, and (c) student behavior. Ultimately, the study showed that despite the tensions that arose in the three themes, the teacher residents did make advances in their teaching that provided more opportunities for inclusive education to be practiced at the PLSs. The present study was designed as a follow up to Kozleski et al. (2013) to understand if the teacher residents' experiences in UTEP were transformative and sustained four years later. The first author was involved in the development of the program and subsequent research studies. She wanted to study the degree to which the original program graduates made sustained changes in their teaching practice and how what they learned in their studies transferred to their practice. Four years later, she returned to the professional learning schools to discover what long-term changes, if any, occurred.

To understand the sustained impact that UTEP had on the teachers' practices, this study addressed the following question: How the UTEP teachers transformed professional practices as a result of being a resident in the program four years later? To address this question, the first author interviewed the UTEP residents, observed them in their classroom teaching and interacting with their students four years after program completion, and cross-referenced their findings with the analysis of their applied projects/archived documents that were created during their program.

\section{Method}

\subsection{Participants and Settings}

The participants included in the study were five former graduates from cohort 1of UTEP, three white and two Latina. These participants were selected based on the criteria that they were still teaching in an urban school setting. All five of the teachers had more than 5 years of teaching experience and they entered UTEP so they could better meet the needs of all their students in an urban setting. These teachers were from two elementary schools located in an urban inner-city school district in a southwestern state in the US. The school district serviced 21 schools with approximately 12,000 students. The 21 schools in the district consisted of 14 elementary schools that ranged from grades kindergarten through five, a developmental special needs school, four middle schools that served grades six through eight, and a K-8 traditional school. The district was an urban district and was in one of the largest metropolitan areas in the US. Unfortunately, the school district did not meet their annual yearly progress goals for several consecutive years prior to the conception of UTEP in 2010. In response, the district was under a great deal of pressure from the state department of education and the district to meet the increasing number of accountability demands (Kozleski et al., 2013).

School 1 was in a low-income neighborhood with a large number of Latino and Yaqui students. When UTEP started, Latino students comprised $60 \%$ of the 750 students in School 1, while students with Yaqui background comprised $22 \%$ of the total enrollment. African American students comprised 9\% while students from Asian background comprised less than one percent, and White students compromised $8 \%$ of School 1's student enrollment. ELLs accounted for $46 \%$ of the school population compared to the state average of $16 \%$, and $94 \%$ of ELLs report Spanish as their home language. Furthermore, $84 \%$ of the families whose students attended School 1 qualified for the free/reduced lunch program.

School 2 was located in a working class neighborhood and it had a long history of being a neighborhood school. This meant that all students attending School 2 were not bussed to the school; they walked since they lived in the neighborhood. There were 852 students enrolled at School 2 from which 74\% came from a Hispanic background and 17\% came from an African-American background. Only 4\% of the population of the school came from a White background, 3\% from a Native American background, and 2\% were Asian/Pacific Islander. English 
language learners compose $59 \%$ of the school population, and students eligible for the free or reduced-price lunch program made up $89 \%$ of School 2's student population.

\subsection{Process Design}

The research design consisted of two phases. During Phase 1, the teachers' applied projects were analyzed using thematic analysis. The first author examined the applied projects and identified themes from each semester-identity, culture, learning, and assessment-across all participants. These themes would later be compared to the thematic outcomes found in the interview and observational data. In addition, the first author worked closely with the school district during this phase to secure support in visiting the teachers' classrooms in Phase 2. After receiving district approval, the teachers were contacted to confirm their participation in classroom observations and interviews.

In Phase 2, participant observations and semi-structured interviews were conducted while data was being coded and analyzed simultaneously. The lead researcher interviewed the teachers, took notes, and recorded their responses (see Appendix A). The interview questions were created in hopes to capture pertinent information from each semester, including the Performance Based Assessments (PBAs) that were measured. Code words and phrases were listed under each question that the researcher listened for during the interviews. These codes were later used to develop themes. In addition, clarification probes were asked when needed to clarify information.

Three days (Monday through Wednesday) from 8:00 a.m. until 3:30 p.m., at each school site observations were conducted of the teachers' professional practices (see Appendix B). The following week on Monday and Tuesday, the researcher returned to the school to conduct member checks and interview the participants. At the beginning of year, informal visits to the school sites were made so the first author could spend a day with the teachers and get to know their students since the researcher would be returning later in the semester to collect data. By visiting the participants and their students earlier, little to no time was needed during the data collection week for getting to know the students or the classroom dynamics. Since there were multiple teachers at each school site, the lead author would observe one teacher while the other was at a "special" (i.e., music, physical education) and then vice versa. Using this approach allowed her to maximize the researcher's time at the school while collecting data.

\subsection{Data Analysis}

As previously noted, there were three sources of data for this study: semi-structured interviews, observational tool with notes, and archived documents from UTEP program (participants' applied projects) (see Appendix C). Using a grounded theory lens, the lead researcher applied the constant comparative method to code and analyze the data at the same time to develop concepts (Taylor \& Bogdan, 1998). Grounded theory was developed by Glaser and Strauss (1967). It was an approach in which theory emerged through qualitative data analysis. When researchers used grounded theory, they utilized a variety of platforms to gather, categorize, and refine the data (Strauss \& Corbin, 1990). In order to develop grounded theory, the literature reported that making constant comparisons and applying theoretical sampling was required (Creswell, 2007; Strauss \& Corbin, 1990; Taylor \& Bogdan, 1998).

The constant comparative method "combines systematic data collection, coding, and analysis with theoretical sampling in order to generate theory that is integrated, close to the data, and expressed in a form clear enough for further testing" (Conrad, Neumann, Haworth, \& Scott, 1993, p. 280). As a result of using the constant comparative method, the data revealed emerging themes from the interviews, observational tool/notes, and applied projects that allowed the researcher to examine what makes the data different and/or similar.

Riessman (2008) delineated four main methodological approaches to narrative analysis: thematic, structural, dialogic/performance, and visual. Thematic analysis was employed to analyze the content of the teachers' narratives and not on the style of their writing. Thematic meanings and the point of narrative were emphasized over language and form. Thematic coding involved identifying passages of text that were related by a common theme and cataloging them into categories to discover thematic ideas. Thematic coding sheet was utilized for the applied projects to organize the data.

\section{Results and Findings}

The data from this study supports that all the participants made a transformation in their thinking that had impacted aspects of their professional practices in some way. The transformation in the teachers' thinking made them more cognizant of who they are and how that impacts their professional practices. The way the teachers think about their teaching practices, their students and their families, and evidence best practices, was altered in UTEP and is still sustained today. In this section, we describe the responses of teachers after being out of the 
program.

Even four years later, the interview and observational data show that the transformation in the teachers' thinking about issues regarding identity, culture, learning, and assessment has been maintained and corroborates the data found in the archived documents and applied projects from 2010. The data also shows that prior to their experience in UTEP, some teacher residents had preconceived ideas about their students and their families that they no longer have. Nina admitted that she thought she understood her students and their families in the past but discovered she was judgmental. Nina explained, "I used to think my kids were brought up like me, but now I think about where my students are coming from to be supportive of their different needs...I want my students to bring their culture into the classroom". The lead researcher followed up with Nina and asked her what she meant by "brought up like me." She replied, "I thought my students had similar experiences to me growing up." In regards to teaching and assessment, Nina talked about using culturally responsive teaching strategies. She incorporates her students' cultures into her teaching. "I use topics or pictures from students' culture in assessment and learning practices". Because of Nina's experience in UTEP, she thinks about where her students come from now so she can support their learning.

Noelle echoed Nina's thinking and shared that she keeps the book that was utilized in the culture semester on hand as a resource. "I refer back to the book we used in the culture semester to develop cross cultural competency. I understand that there are other cultural norms". Noelle also shared that she utilizes Positive Behavior Intervention Support (PBIS). "In my position now as a special education teacher I am using PBIS and working with the RtI team before a student is referred to special education for testing".

Debbie discussed utilizing more multicultural material in her classroom to meet the needs of her students. Debbie explains, "I try to incorporate multicultural material across all subjects". I asked Debbie what she meant by multicultural material and she stated that she uses a variety of books and examples that represent different cultures.

Kim has recognized that she is continuing to learn about who she is. As Kim continues to learn more about her identity, she actively supports her students doing the same. "I am continuing to learn about my identity so I can assist my students in learning about who they are. I love learning about different cultures!" When I asked Kim what she meant by "continuing to learn," she said that "our identity is always changing." It was clear that Kim was still learning about her identity and was excited to learn about her students. It has been four years since Kim began the urban teacher preparation program, so I believe it is safe to assume that Kim's recognition that identity is not static and continues to evolve was influenced by her experience in the program. Both schools in the study have implemented RtI. Kim shared that she likes "that students are placed in different tiers that assist them before they are tested for special education".

Breanne also addressed her identity and shared how it had changed since learning about her own heritage as a result of her involvement with the program. Breanne spoke about her Latino heritage as being a huge part of her identity. She shared, "I am a Latina. I know what it is like to feel marginalized so I want all my students to be comfortable with who they are and where they come from". Since Breanne alluded to having experiences in which she felt marginalized. The lead researcher probed her more by asking her if she could provide an example of being marginalized. Breanne did not hesitate to provide a recent example. She shared, "I had difficulty with a teacher on staff. People referred to it as a personality conflict, but it was more than that, I knew the teacher had issues with me being Latina and felt that I was less than her." Because of Breanne feeling she has been marginalized, she makes every attempt to have her students respect individual differences in her classroom. "I rearrange my students' desk every week to make sure they work with different peers. This helps students learn more about each other and respect different viewpoints." The lead researcher had Breanne clarify what she meant by viewpoints and she expanded, "Viewpoints as in different beliefs."

When the first author observed the UTEP teachers their classrooms were configured so the students were able to move around the room freely and access materials (i.e. books, manipulatives, and school supplies). It was evident that the teachers were practicing elements of UDL by providing their students with a variety of strategies to match their learning styles, allowing students to show what they learned in multiple ways, and honing in on students' interest and utilizing that information in lessons to increase student engagement (Rose \& Meyer, 2002, 2006; Rose, Meyer, \& Hitchcock, 2005).

\section{Implications}

The research in the last decade gives us hope about the future of teacher education by revealing a new perspective on programmatic designs. This study's findings reinforce Milner's (2011) research, which maintains that courses can be designed in teacher preparation programs to provide pre-service teachers with learning spaces 
to assist them in developing the foundation and understanding that is essential when teaching in diverse settings. Milner advocates that "courses need to be developed that focus on the reality of these schools, the diversity as well as the homogeneity that are present within them, and on the knowledge and understanding necessary to meet the needs of all students" (p. 345).

Some programs have successfully been restructured to meet the needs of all students by integrating special and general education into one program (Pugach, Blanton, \& Correa, 2011). By having an integrated program that promotes teacher inquiry, teachers are presented with opportunities to explore the role culture plays in teaching and learning (Waitoller, \& Kozleski, 2013). By formulating an inquiry perspective and collaborating with others, teacher candidates feel enabled to make novel, relevant, and meaningful choices for their students that are not necessarily promoted in the traditional cultures of teaching (Dana \& Yendol-Silva, 2003; Mule, 2006).

The data from this study reinforces the findings from the original study (Kozleski et al., 2013). We found that with increased opportunities to engage in critically reflective practices, the teachers began to understand their students and recognized areas of their teaching practices that needed to be addressed to make learning more equitable.

Our hope is that all teacher preparation programs will include spaces and opportunities for preservice teachers where they are able to engage in critical reflection about how to teach children who come from different backgrounds. This study provides evidence that participation in UTEP, a program that shares these values, resulted in sustained, meaningful change in teachers' practices as a result of their experience in UTEP. The most significant change that took place in all the teachers was the transformation in their thinking. Whether it was deliberating about issues related to identity, culture, learning, and/or assessment, UTEP provided the teachers with numerous spaces to cross-examine their own thinking and, ultimately, making an impact on the way they think about their teaching practices years later.

\section{Conclusion}

The odds are high that children of color will spend most of their educational experience working primarily with a white teaching force, so it is essential to include critical reflective practices in the design of teacher education programs. In UTEP, we included reflective opportunities for our preservice teachers and our findings confirm that this feature was effective. The goal should be to retain teachers, so if preservice teachers have spaces to think deeply about what it means to teach in unfamiliar territory and get to know their students and school community, then we are more likely to keep them in the profession.

\section{Acknowledgements}

The author wants to acknowledge the support of the Office of Special Education Programs grants H325T070009, H325D080027, and H325P060012. Ideas and opinions expressed herein do not necessarily reflect the policy of the Department of Education, and no official endorsement by the Department should be inferred.

\section{References}

Anyon, J. (1997). Ghetto schooling: A political economy of urban educational reform. New York, NY: Teachers College Press.

Aud, S., Hussar, W., Kena, G., Bianco, K., Frohlich, L., Kemp, J., \& Tahan, K. (2011). The Condition of Education 2011 (NCES 2011-033). U.S. Department of Education, National Center for Education Statistics. Washington, DC: U.S. Government Printing Office.

Blackburn, S. (2019). What is the model minority myth?. Retrieved from https://www.tolerance.org/magazine/what-is-the-model-minority-myth

Buendia, E. (2010). Reconsidering the urban in urban education: Interdisciplinary conversations. Urban Review, $43,1-21$.

Conrad, C., Neumann, A., Haworth, J. G., \& Scott, P. (1993). Qualitative research in higher education: Experiencing alternative perspective and approaches. Needham Heights, MA: Ginn Press.

Creswell, J. W. (2007). Research design: Qualitative and quantitative approaches (2nd ed.). Thousand Oaks, CA: Sage.

Dana, N., \& Yendol-Silva, D. (2003). The reflective educator's guide to classroom research: Learning to teach and teaching to learn through practitioner inquiry. Thousand Oaks, CA: Corwin Press.

Gershenson, S., Holt, S. B., \& Papageorge, N. W. (2015). Who believes in Me? The effect of student-teacher demographic match on teacher expectations. Upjohn Institute Working Paper 15-231. Kalamazoo, MI: W.E. 
Upjohn Institute for Employment Research. https://doi.org/10.17848/wp15-231

Glaser, B., \& Strauss, A. (1967). The discovery of grounded theory. Aldine Publishing Company. Hawthorne, NY.

Goodlad, J. I. (1990). Teachers for our nations'schools. San Francisco, CA: Jossey-Bass.

Gutierrez, K. D., Asato, J., Pacheco, M., Moll, L. C., Olson, K., \& Horng, L. E. (2002). "Sounding American”: The consequences of new reforms on English language learners. International Reading Association, 37, 328-343.

Hoffman, P., Dahlman, A., \& Zierdt, G. (2009). Professional learning communities in partnership: A 3-year journey of action and advocacy to bridge the achievement gap. School-University Partnerships, 3, 28-42.

Howard, T. (2003). Culturally relevant pedagogy: Ingredients for critical teacher reflection. Theory into Practice, 42, 195-202.

Kozleski, E. B., \& Smith, A. (2009). The role of policy and systems change in creating equity for students with disabilities in urban schools. Urban Education, 44, 427-451.

Kozleski, E. B., \& Waitoller, F. R. (2010). Teacher learning for inclusive education: Understanding teaching as a cultural and political practice. International Journal for Inclusive Education, 14, 655-666.

Kozleski, E. B., Gonzalez, T., Atkinson, L., Lacy, L., \& Mruczek, C. (2013). Teacher education in practice: Reconciling contexts, practices, and theories. European Journal of Special Needs Education, 28, 156-172.

Milner, H. R. (2006). Pre-service teachers' learning about cultural and racial diversity: Implications for urban education. Urban Education, 41, 343-375.

Mule, L. (2006). Pre-service teachers' inquiry in a professional development school context: Implications for the practicum. Teaching and Teacher Education, 22, 205-218.

Pugach, M. C., Blanton, L. P., \& Correa, V. I. (2011). A historical perspective on the role of collaboration in teacher education reform: Making good on the promise of teaching all students. Teacher Education and Special Education, 34, 183-200.

Riessman, C. (2008). Narrative methods in the human sciences. Thousand Oaks, CA: Sage.

Rose, D. H., \& Meyer, A. (2002). Teaching every student in the digital age: Universal design for learning. Alexandria, VA: ASCD.

Rose, D. H., \& Meyer, A. (2006). A practical reader in universal design for learning. Cambridge, MA: Harvard Education Press.

Rose, D. H., Meyer, A., \& Hitchcock, C. (2005). The universally designed classroom: Accessible curriculum and digital technologies. Cambridge, MA: Harvard Education Press.

Singer, N. R., Catapano, S., \& Huisman, S. (2010). The university's role in preparing teachers for urban schools. Teaching Education, 21, 119-130.

Strauss, A., \& Corbin, J. (1990). Basics of qualitative research. Newbury Park, CA: Sage.

Taylor, S. J., \& Bogdan, R. (1998). Introduction to qualitative research methods: A guidebook and resource (3rd ed.). New York: Wiley.

Ukpokodu, O. N. (2004). The impact of shadowing culturally different students on preservice teachers' disposition toward diversity. Multicultural Education, 12(2), 19-28.

Waitoller, F., \& Kozleski, E. B. (2013). Working in boundary practices: Identity development and learning in partnerships for inclusive education. Teaching and Teacher Education, 31, 25-45. 


\section{Appendix A}

\section{Interview Questions for Teachers}

Interview Questions for Teachers:

1. How do you view your identity in a multi-cultural, urban setting?

- Listen for: teacher inquiry-thinking about their beliefs and values and how they impact their professional practice. Critical reflexive practices.

2. In what ways do you feel more prepared to work with children who come from different backgrounds than your own?

- Listen for: culturally responsive teaching practices, encourage family participation, learn about students' cultures, community assets maps

3. Explain how your learning and assessment practices honor your identity and your students' cultures.

- $\quad$ Listen for: differentiated Instruction, UDL, PBIS, RTI, progress monitoring

4. How do you view your students' cultures?

- $\quad$ Listen for: what students bring from prior experiences.

5. Is there anything else you took away from your Master's program that has impacted your teaching practices in an urban setting?

\section{Appendix B}

\section{Observational Tool}

\section{SCHOOL VISIT/CLASSROOM OBSERVATION TOOL}

Date: Class Observed:

Transforming: Teacher's thinking and work reflect a depth in their knowledge, skills, dispositions and values in diverse society.

Developing: Teacher demonstrates practice during planning and instruction.

Early: Teacher understands the importance of learning about and planning for the practice.

\begin{tabular}{|l|l|l|l|}
\hline $\begin{array}{c}\text { Transforming } \\
\text { Descriptor }\end{array}$ & \multicolumn{1}{|c|}{ Early } & \multicolumn{1}{c|}{ Developing } & \multicolumn{1}{c|}{ Transforming } \\
\hline & $\begin{array}{l}\text { Teacher incorporates } \\
\text { materials from students } \\
\text { culture and lived } \\
\text { experiences in ways that } \\
\text { allow some students to } \\
\text { make meaningful } \\
\text { connections. }\end{array}$ & $\begin{array}{l}\text { Teacher curricular materials } \\
\text { reflect students' personal } \\
\text { cultures and experiences in } \\
\text { ways that bridges gaps in } \\
\text { understanding for some } \\
\text { students while other students } \\
\text { still may remain } \\
\text { disconnected. }\end{array}$ & $\begin{array}{l}\text { Teacher creates lessons to offer } \\
\text { opportunities to explore complex } \\
\text { identities and reflect on various } \\
\text { social and racial group experiences. } \\
\text { A variety of teaching strategies are } \\
\text { used to provide students with } \\
\text { opportunities to engage in } \\
\text { discussions about equity, social } \\
\text { justice, and aspects of history that } \\
\text { have been left out of the curriculum. }\end{array}$ \\
& $\begin{array}{l}\text { Teacher uses a limited } \\
\text { array of strategies and } \\
\text { activities to create learning } \\
\text { experiences that meet the } \\
\text { instructional needs of many } \\
\text { students, however some } \\
\text { students with diverse } \\
\text { learning needs and } \\
\text { preferences struggle to } \\
\text { actively participate and } \\
\text { make progress. Teacher } \\
\text { seldom reflects on own } \\
\text { practice. }\end{array}$ & $\begin{array}{l}\text { Teacher uses a variety of } \\
\text { strategies and activities to } \\
\text { create learning experiences } \\
\text { that effectively meet the } \\
\text { instructional needs of most } \\
\text { students; and includes } \\
\text { accommodations to respond } \\
\text { to students who struggle. } \\
\text { The teacher occasionally } \\
\text { reflects on his/her own } \\
\text { practice. }\end{array}$ & $\begin{array}{l}\text { Using an anti-bias pedagogy, teacher } \\
\text { promotes positive perspectives on } \\
\text { parents and families of culturally and } \\
\text { linguistically diverse students. A } \\
\text { variety of teaching strategies are } \\
\text { being used to actively engage } \\
\text { students and the strategies are } \\
\text { connected to different learning } \\
\text { styles; including cooperative, peer } \\
\text { and project based learning, } \\
\text { audio-visual presentations, lecture, } \\
\text { discussions, and inquiry. The teacher } \\
\text { reflects on his/her practice regularly. }\end{array}$ \\
\hline \multirow{20}{*0}{} & &
\end{tabular}




\begin{tabular}{|c|c|c|c|}
\hline 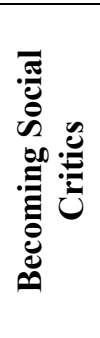 & $\begin{array}{l}\text { Teacher introduces ways in } \\
\text { which students can identify } \\
\text { how cultural patterns } \\
\text { inform and define } \\
\text { identities, power } \\
\text { relationships, and infuse } \\
\text { everyday activities of } \\
\text { learning and socializing. }\end{array}$ & $\begin{array}{l}\text { Teacher provides leadership } \\
\text { for examining the ways in } \\
\text { which cultural patterns } \\
\text { inform and define identities, } \\
\text { power relationships, and } \\
\text { infuse everyday activities of } \\
\text { learning and socializing. }\end{array}$ & $\begin{array}{l}\text { Teacher helps students to become } \\
\text { social critics by developing skills, } \\
\text { knowledge and values necessary for } \\
\text { making reflective decisions and } \\
\text { implementing them in effective } \\
\text { personal, social, political, and } \\
\text { economic action. }\end{array}$ \\
\hline 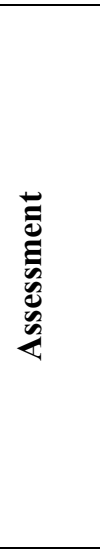 & $\begin{array}{l}\text { Teacher uses a limited } \\
\text { array of assessment } \\
\text { strategies to determine } \\
\text { students' learning of } \\
\text { specific information or } \\
\text { skills. Students are } \\
\text { provided few opportunities } \\
\text { to demonstrate mastery of } \\
\text { skills using their own } \\
\text { cultural knowledge. }\end{array}$ & $\begin{array}{l}\text { Teacher uses multiple } \\
\text { assessment methods to } \\
\text { account for different ways of } \\
\text { learning and provide some } \\
\text { opportunities for students to } \\
\text { demonstrate new learning by } \\
\text { building on their own } \\
\text { cultural knowledge. Teacher } \\
\text { sometimes uses assessment } \\
\text { information during teaching } \\
\text { to inform instructional } \\
\text { practices. }\end{array}$ & $\begin{array}{l}\text { Teacher continuously assesses } \\
\text { students' knowledge using a variety } \\
\text { of strategies that allow them to } \\
\text { incorporate their own cultural } \\
\text { knowledge and show their ability to } \\
\text { apply newly learned information. } \\
\text { Teacher both formally and } \\
\text { informally assesses students' } \\
\text { knowledge prior to instruction to } \\
\text { prepare a lesson, during instruction } \\
\text { to inform and adjust teaching and } \\
\text { after instruction to assess student } \\
\text { outcomes. }\end{array}$ \\
\hline 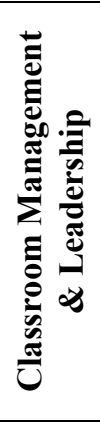 & $\begin{array}{l}\text { The classroom rules and } \\
\text { expectations are } \\
\text { ineffective. Students are } \\
\text { disengaged and off-task } \\
\text { behavior is observed. } \\
\text { Teacher is reinforcing } \\
\text { negative behavior opposed } \\
\text { to positive behavior. }\end{array}$ & $\begin{array}{l}\text { The classroom rules, } \\
\text { expectations and procedures } \\
\text { lessen some student } \\
\text { discipline/behavior, and } \\
\text { provide some evidence of } \\
\text { student engagement. Positive } \\
\text { behavior supports are } \\
\text { inconsistent and there are } \\
\text { limited strategies being used } \\
\text { to redirect off-task behavior. }\end{array}$ & $\begin{array}{l}\text { The classroom rules, expectations } \\
\text { and procedures are designed to } \\
\text { reduce down time and promote } \\
\text { student engagement. Positive } \\
\text { behavior supports are used to } \\
\text { prevent and redirect disruptive } \\
\text { behaviors. Reinforcement of } \\
\text { school-wide norms and use of } \\
\text { school-wide routines is evident. }\end{array}$ \\
\hline 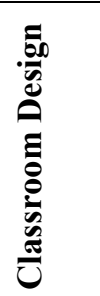 & $\begin{array}{l}\text { Minimal examples of } \\
\text { student work are displayed. } \\
\text { The classroom design is } \\
\text { more teacher-centered than } \\
\text { student-centered. The } \\
\text { classroom arrangement is } \\
\text { not flexible for all students. }\end{array}$ & $\begin{array}{l}\text { Student work is displayed. } \\
\text { The classroom design is } \\
\text { more student-centered than } \\
\text { teacher-centered. The } \\
\text { classroom arrangement is } \\
\text { flexible for most students. }\end{array}$ & $\begin{array}{l}\text { Anchor charts are on walls to } \\
\text { support student work and to reflect } \\
\text { establishment of expectations and } \\
\text { routines; flexible arrangement of } \\
\text { furniture; a variety of student work is } \\
\text { displayed. Accommodations are in } \\
\text { place to support all students. }\end{array}$ \\
\hline
\end{tabular}

\footnotetext{
Adapted from

http://essentialschools.org/wp-content/uploads/2015/01/Culturally_Responsive-ObservationTool.pdf https://tntp.org/assets/documents/TNTP_RatingATeacherObservationTool_Feb2011.pdf
} 


\section{Appendix C}

Applied Project- Narrative Analysis (Thematic Approach)

Name

\begin{tabular}{lcc}
\hline Semester & Key Ideas & Quotes \\
\hline IDENTITY &
\end{tabular}

CULTURE

LEARNING

ASSESSMENT

\section{Copyrights}

Copyright for this article is retained by the author(s), with first publication rights granted to the journal.

This is an open-access article distributed under the terms and conditions of the Creative Commons Attribution license (http://creativecommons.org/licenses/by/4.0/). 